\title{
USE OF THE ICHTHYOHAEMATOLOGICAL STUDIES IN ECOLOGICAL MONITORING OF THE RESERVOIRS
}

\author{
G. G. SERPUNIN, O. A. LIKHATCHYOVA \\ Kaliningrad State Technical University, Kaliningrad, Russia \\ Received July 22, 1998 \\ Accepted September 21, 1998
}

\begin{abstract}
Serpunin, G. G., O. A. Likhatchyova: Use of Ichthyohaematological Studies in Ecological Monitoring of the reservoirs. Acta vet. Brno 1998, 67: 339-345.

The aim of our investigation was to determine the character of influence of some environmental factors on the fish blood indices, and to explore the use of haematological methods for ecological monitoring. We studied red blood indices of the bream in Kurshsky and Kaliningradsky lagoons in 1996 and compared them to values found in 1971. Apart from complete blood count and haemoglobin concentrations, the morphometric analysis of erythrocytes was carried out. The character of correlations between blood indices and some hydrochemical and hydrobiological environmental variables was analysed.

The erythrocyte sizes were directly correlated with water temperature, chlorides and different forms of nitrogen concentrations, with biomass and abundance of the food invertebrates. The haemoglobin concentration was directly correlated with water temperature, chlorides, oxygen and total phosphorus concentrations, number of chironomids, and inversely correlated with concentrations of mineral nitrogen and phosphorus. The leukocyte counts were directly correlated with water temperature, oxygen and phosphorus concentration. The complete white blood count was the most changeable blood parameter. Our data obtained in the bream verified the inverse correlation between erythropoiesis and leukopoiesis. Erythropoiesis was more affected by the food of fish and was less dependent on the changes of water temperature. Leukocyte counts correlated with the water temperature, and less with the amount of food. The complete white blood count of the bream was affected not only by temperature, but also by hydrochemical situation, affecting the relationship between different forms of leukocytes. The respective numbers of the white blood cell elements was correlated with the water temperature, content of chlorides, oxygen. different nitrogen forms and mineral phosphorus concentrations.

Comparison of the present results with those obtained in Kaliningradsky lagoon in 1971 indicates a decrease of water alkalinity, incease of chloride. mineral and total nitrogen content, and improvement of food base in the lagoon during the last 25 years. The lagoon became more salty and more eutrophic.
\end{abstract}

\section{Bream (Abramis brama), haematological indices, morphometry, erythrocytes}

When evaluating the hydrobiological situation of the waters with fish of industrial importance fish should be the obligatory object of such investigations and most important indicator organisms. Lukianenko (1983) demonstrated that fish are especially suitable and should become basic objects for toxicological studies as well as for biotesting. This is possible due to large amount of material, collected and analysed worldwide. Furthermore, fish should be protected from environmental pollution since they are an important and highly sensitive component of aquatic ecosystems, and source of food for human population.

The aim of our investigations was to determine the influence of some environmental variables on the fish blood indices and show that haematological methods provide a suitable tool for ecological monitoring. 
At present, haematological studies of the fish are of great importance. Many fish species are intensively studied when the analysis of different pollution effects on aquatic organisms is carried out. Blood indices are reliable indicators of the state of health of an organism, and mirror the conditions of its existence.

It reflects readily the environmental changes and indicates exactly the physiological state or any deviations from health (Ivanova 1995).

\section{Materials and Methods}

Blood samples were collected from bream in Kurshsky and Kaliningradsky lagoons of the Baltic Sea in September 1971 and May-July 1996 during expeditions on AtlantNIRO ships. Four expeditions (3 in Kurshsky and 1 in Kaliningradsky lagoons) were carried out in 1996. During each of them two blood samples were taken on the fixed stations. Each sample consisted of about 10 fish specimens that were caught by trawl.

A total of 52 fishes Kurshsky lagoon aged 4 to 10 years and weighing 350 to $1480 \mathrm{~g}$ were caught. The hydrochemical and hydrobiological conditions of the lagoon in the period under study were determined by collaborators of Atlant NIRO hydrochemical laboratory and lagoon laboratory. Fig. 1 depicts the sampling areas, the second station is near Zelenogradsk, the seventh station is near Golovkino.

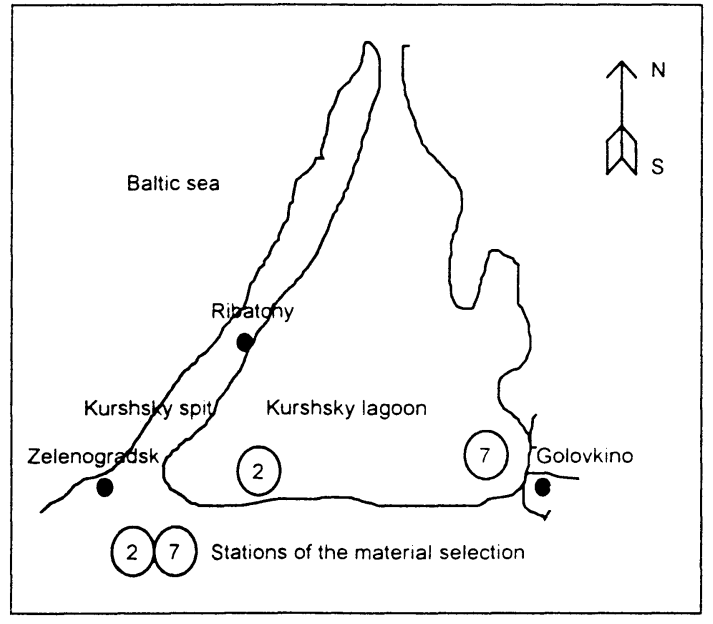

Fig 1.

Kurshsky lagoon

The blood of bream in the Kaliningradsky lagoon was collected two times in 1971 (in June 18 fish and in September 25 fish were investigated, and in July 1996 on two stations ( 20 fish from Kaliningradsky lagoon aged 3 to 11 years and weighing 320 to $3100 \mathrm{~g}$ were analysed). The numbers of stations AtlantNIRO classification were the same. The second station is near the Svetly, the ninth is in the center of Primorsk bay at the equal distance from Svetly, Primorsk and Baltiysk (Fig. 2).

The blood was collected from caudal artery of the fish immediately after it had been caught, and placed into the conserving solution of Trombitsky (1988), in which the erythrocytes were preserved until the end of the second week after collection. The erytrocyte counts were determined in the Goriaev chamber under the microscope, and the leukocyte counts were determined using an indirect method were (Serpunin and A mine va 1986).

The haemoglobin concentration was measured using the haemoglobincyanid method (Serpunin and A mineva 1986). Concentration of total protein in the blood serum was determined using the coefficient of serum refraction as measured with a refractometer.

The blood smears were stained in the Kiev apparatus the Pappenheim method using May-Grünwald and GiemsaRomanowski dyes.

The microscopical analysis of the fish blood elements was carried out on the stained preparations using the image analysis system "Videotest". The computer program of this system made it possible to obtain measurements of different erythrocyte dimensions, to statistical calculation of the results (Serpunin 1998).

The complete white blood count was made in blood smears calculating 200 leukocytes in microscope. To identify the leukocytes, classification of the fish blood cells by I va nov a (1983) was used. The calculation of the leukocyte 


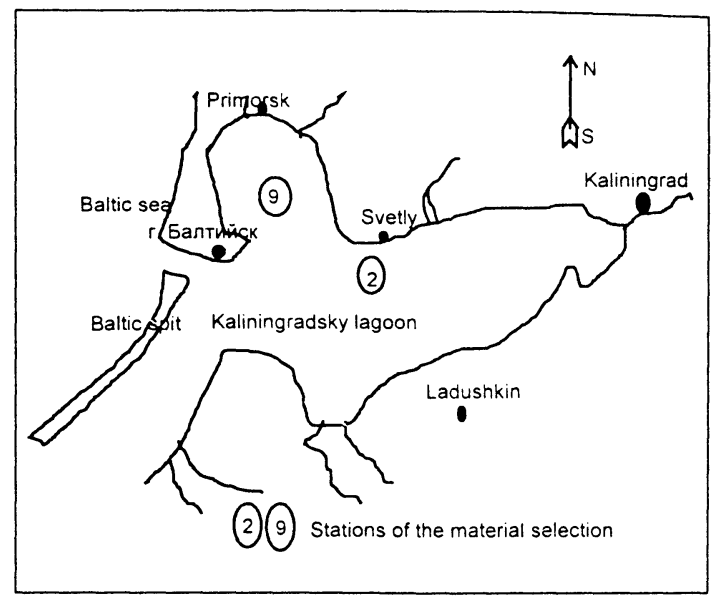

Fig 2.

Kaliningradsky lagoon

formula was carried out for the following groups of leukocytes: promyelocytes (Pmc), myelocytes (Mc), metamyelocytes $(\mathrm{Mmc})$, band neutrophils $(\mathrm{Nb})$, segmented neutrophils $(\mathrm{Ns})$, pseudobasophils ( $\mathrm{Pba}$ ), eosinophils (Eo), pseudoeosinophils (Peo), monocytes (Mo), small and large lymphocytes (Ly) and cells with vacuolized cytoplasm (Vcc).

The obtained data were statisticaly evaluated. The correlation analysis between blood indices and hydrochemical variables and food base of the bream was made. Significance of the changes in blood indices was proved with the Student t-test.

\section{Results}

\section{Kurshsky lagoon}

Our results indicate a significant reduction $(\mathrm{P}<0.05)$ of the majority of blood indices from May to June and their sharp increase in July. Area (Fig. 3), perimeter (Fig. 4), factor circle form, minor axis length (Fig. 5) of the erythrocytes, and respective numbers of the Peo, $\mathrm{Pba}$, Mo (Fig. 7) were changed in a similar manner.

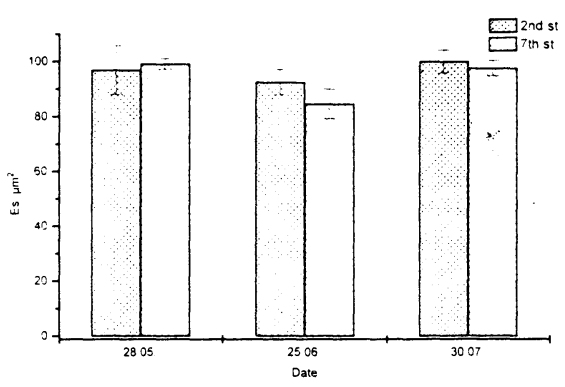

Fig 3 .

Changes of the erythrocytes square (Es) of breams from the Kurshsky lagoon during studied season at different stations (st.)

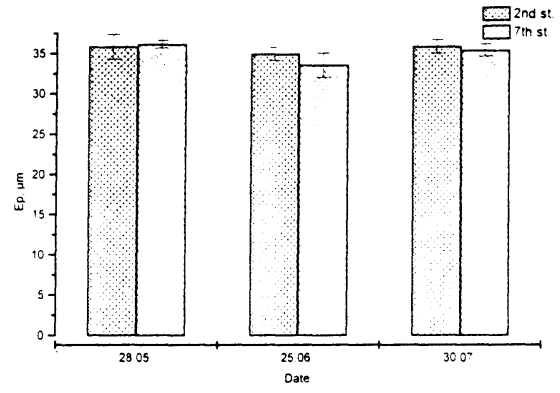

Fig 4.

Changes of the erythrocytes perimeter (Ep) of breams from the Kurshsky lagoon during studied season at different stations (st.)

The haemoglobin concentration (Fig. 6), erythrocyte roundness, Mmc quantity (Fig. 7) were changed non-significantly in June but sharply increased in July $(\mathrm{P}<0.05)$. 


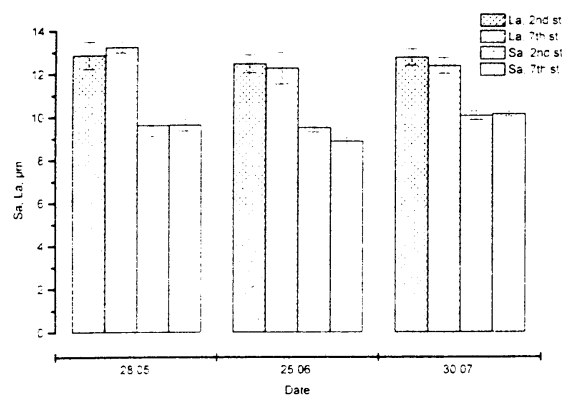

Fig 5.

Changes of minor (Sa) and major (La) axis lenghts of the erythrocytes of bream from the Kurshsky lagoon during studied period at different stations (st.)

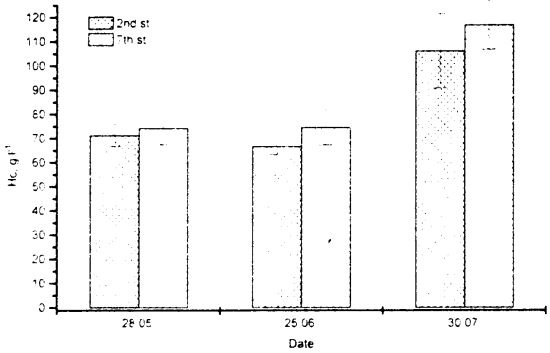

Fig 6.

Changes of minor (Sa) and major (La) axis lenghts of the erythrocytes of bream from the Kurshsky lagoon during studied period at different stations (st.)

Mc (Fig. 7) and Vcc (Fig.8) amount have constantly increased during the observation period $(\mathrm{P}<0.05)$.

The length of the long axis (Fig. 5) and relation of the erythrocytes axis length, $\mathrm{Nb}$ (Fig. 7) and large Ly numbers (Fig. 8), in contrast, were reduced from May to July $(\mathrm{P}<0.05)$.

Small Ly count (Fig. 8) increased in June and was reduced in July, approaching May figures $(\mathrm{P}<0.05)$.

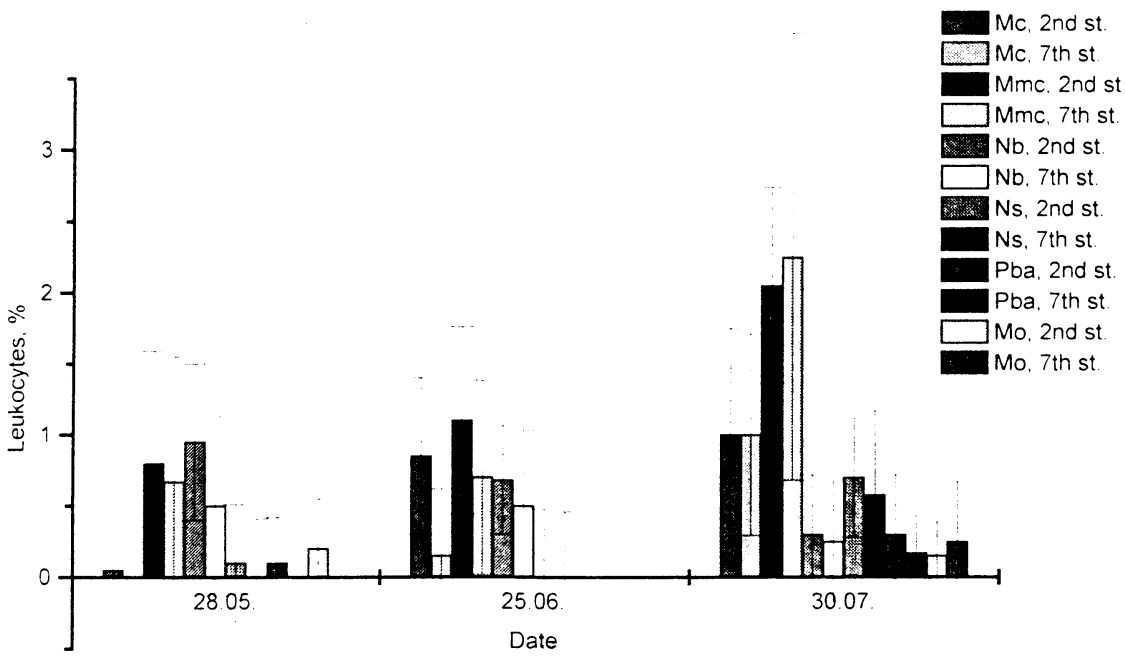

Fig 7.

Changes of the leukocytes of bream from the Kurshsky lagoon during studied period at different stations (st.)

Kaliningradsky lagoon

No differences between fish caught on the various stations in the blood concentration indices and the erythrocyte morphometric indices were found.

However, the blood smears of fish at both stations showed signs of depressed erythropoiesis (anisocytosis, agglutination and poikilocytosis of the erythrocytes) that occurred in reply of the blood system to the toxic effects of environmental factors 


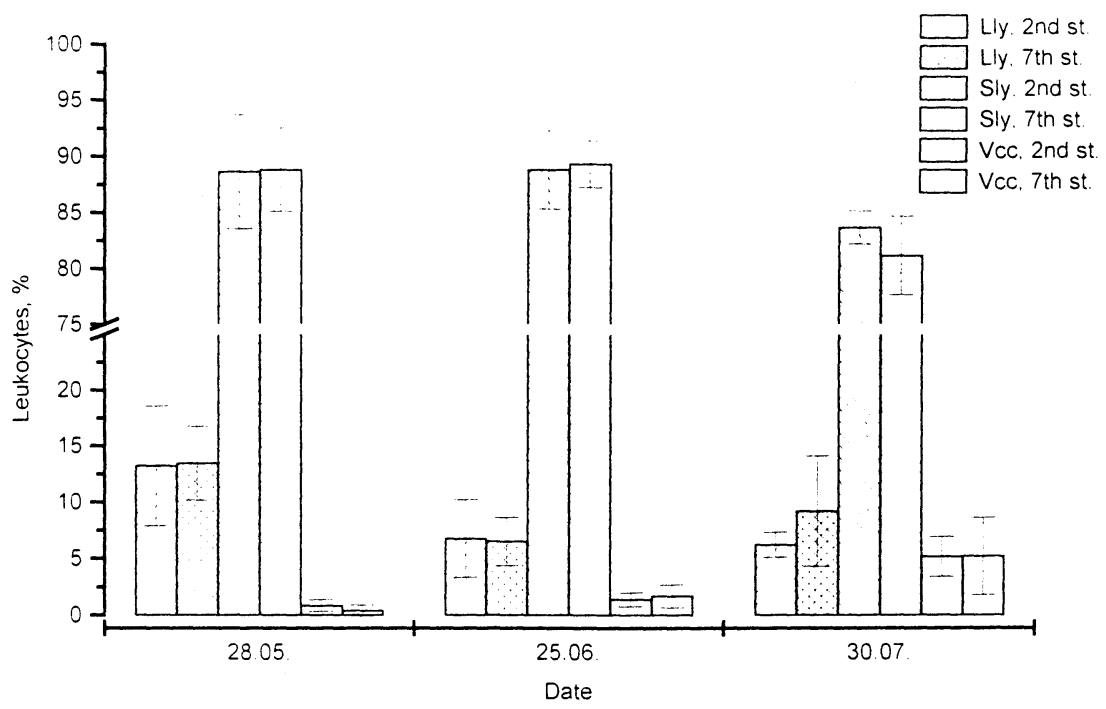

Fig 8 .

Changes of the leukocytes of bream from the Kurshsky lagoon during studied period at different stations (st.)

(Zhiteneva et. al. 1989). These signs were expressed more markedly in fish caught near the second station.

In the WBC and differential WBC no changes were detected in $\mathrm{Mc}, \mathrm{Pba}, \mathrm{Peo}$ on both stations, and on the second station also Mo, $\mathrm{Nb}$ and Ns were absent, large Ly on both stations were detected in about equal numbers. Mmc and Vcc there were significantly more on the 2nd station and small Ly - significantly more on the 9th station $(\mathrm{P}<0.05)$. Increased numbers of young neutrophil forms indicated an enhancement of leukopoiesis likely to occur in response to toxic or infectious effects of environmental factors. Vcc ("frothy" cells), emerging in blood, are indicative of leukocyte degeneration. These variations generally emerge in anemias, caused by toxicoses, infections and invasions (Zhiteneva et al. 1989). Total reduction in white blood cell elements occurs in response to toxic negative environmental status. For example, we observed more intensive leukopoiesis and degeneration of Ly both as signs of adverse conditions in the Kaliningradsky lagoon water, more expressed at the 2nd station, near Svetly.

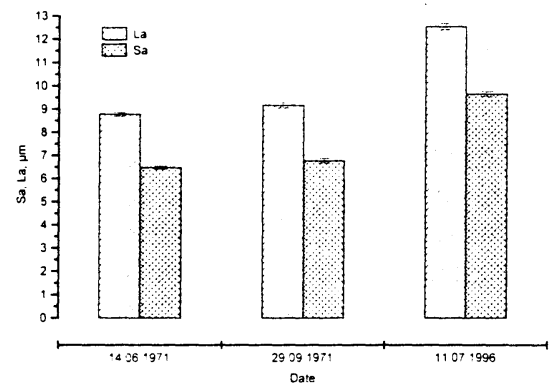

Fig 9.

Changes of amall (Sa) and large (La) axis lenghts of the erythrocytes of bream from the Kaliningradsky lagoon

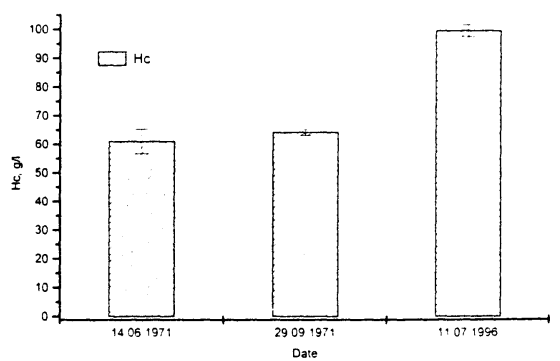

Fig 10.

Changes of the hemoglobin concentration (Hc) in the blood of bream from the Kaliningradsky lagoon 
Our comparative analysis in 1971 (Serpunin 1972) and 1996 reveals the following:

In 1996, erythrocytes of the bream were significantly larger than in 1971: their long axis surpassed that found in 1971 (Fig. 9) significantly $(\mathrm{P}<0.05)$, the values being $8.8 \mu \mathrm{m}$ in June and $9.2 \mu \mathrm{m}$ in September; their minor axis was longer, too $(\mathrm{P}<0.05)$, than that found in 1971 (6.5 $\mu \mathrm{m}$ in June and $6.8 \mu \mathrm{m}$ in September).

On the other hand, no significant differences between area of the erythrocyte surface in $1971\left(90.4-91.2 \mu \mathrm{m}^{2}\right)$ and 1996 have not been found.

The haemoglobin concentration (Fig.10) was higher $(\mathrm{P}<0.05)$ in 1996 compared to than that found in $1971\left(61.0-64.0 \mathrm{~g} \cdot \mathrm{l}^{-1}\right)$.

The erythrocyte and leukocyte concentrations in 1996 were at the approximately equal level with the ones in 1971 (1.197-1.515 T.1.1 and 143.0-161.3 G.l-1 respectively).

\section{Discussion}

For the operative monitoring of water pollution it has been suggested to use the haematological analysis of fish. Fish complete the trophic chain in the water, and accumulate all changes taking place on the lowest stages of the ecological pyramid (Serpunin 1991). Changes in the fish blood indices were investigated and their correlation with environmental factors were discovered. Such an approach made it possible to determine the environmental status of the Kurshsky and Kaliningradsky lagoons and its most marked influences on the physiological condition of the fish.

Erythrocytes of the fish in the Kurshsky lagoon in June as compared to May, were smaller and elongated. Furthermore, intensification of poikilocytosis and anisocytosis, agglutination and oligochromasia were observed. All these signs indicate an impaired erythropoiesis, more pronounced in fish collected at the second station. Sizes of the erythrocytes were significantly correlated with the water temperature, chloride and different nitrogen form concentrations, and the state of the food base. In the differential white blood count the relative amount of Mc (and neutrophils in total), "frothy" cells and small Ly were increased. This indicated a more intensive leukopoiesis, again more pronounced at the second station. These changes in leukocytes were correlated with the water temperature, chloride, oxygen and different nitrogen form concentrations, i.e. with the same environmental factors that were depressing the erythropoiesis. It can be assumed that there had been a serious damage to the environment in June, compared with May (especially on the second station) that caused such a remarkable reaction of the fish.

In July, almost all the red blood indices significantly increased, approaching to May figures and even excessing them (only the erythrocyte count and major axis length were changed, and the relation of the erythrocytes lengths has decreased), i.e. the erythrocytes have enlarged, taking more roundish form, and their haemoglobin concentration increased. Correlated with these indices were the environmental factors in June. They were changed intensively: the water temperature, chloride and total nitrogen concentrations, the state of the food base. In the white blood decreasing of $\mathrm{Nb}$ count and unchanging of Ns count were observed. Increased neutrophil count took place at the expense of young forms: Mc and Mmc. Peo, Pba, Vcc counts increased and small Ly count decreased. Such variations show a more intensive erythropoiesis that occurred as a compensation in response to the toxic effects of environmental factors. However, on the other hand signs of the leukopoiesis normalisation were noted, as in the negative environmental conditions amount of the cell kinds is decreased. We thus discovered some sings of adaptation to environmental conditions in the fish exposed to the continuing effects of toxic factors. This adaptation 
lead even to restored function of the blood system. From the environmental factors we can detach the influence of the water temperature, chlorides, total nitrogen, mineral phosphorus increasing and mineral nitrogen decreasing.

\section{Využití ichtyohematologických metod při ekologickém monitoringu}

Cílem našeho sledování bylo stanovit charakter vlivu některých environmentálních faktorů na parametry krve ryb a zjistit možnosti využití hematologických metod při ekologickém monitoringu. Sledovali jsme parametry červené krevní řady u cejna z Kuršského a Kaliningradského zálivu v roce 1996 a porovnávali je s hodnotami zjištěnými v roce 1971. Kromě stanovení koncentrace hemoglobinu a diferenciálního počtu krevních buněk, bylo provedena i morfometrická analýza erytrocytů. Analyzován byl charakter korelací mezi krevními parametry a některými hydrochemickými a hydrobiologickými ukazateli.

Velikost erytrocytů je přímo závislá na teplotě vody, koncentraci chloridů a dusíkatých sloučenin, na biomase a abundanci potravních bezobratlých. Koncentrace hemoglobinu prímo koreluje s teplotou vody, obsahem chloridủ, kyslíku a celkového fosforu, dále $\mathrm{s}$ množstvím larev pakomárů a nepř́mo koreluje $\mathrm{s}$ koncentrací minerálního dusíku a fosforu. Počet leukocytů je př́mo závislý na teplotě vody, koncentraci kyslíku a fosforu. Diferenciální počet leukocytů je velmi proměnlivým krevním ukazatelem. Naše údaje získané u cejna potvrzují nepř́mou korelaci mezi erytropoézou a leukopoézou.

\section{Acknowledgement}

We are most grateful to our colleagues from AtlantNIRO lagoon laboratory E. N. Naumenko and L. V. Rudinskaya for help to collect the material.

\section{References}

IVANOVA, N. T. 1983: Atlas of the fish blood cells. Moscow, 184 pp.

IVANOVA, N. T. 1995: Blood system. Materials at comparative morphologic of the human and animals blood system. Rostov-on-Don, $155 \mathrm{pp}$.

LUKIANENKO, V. I. 1983: General ichthytoxicology. Moscow, 320 pp.

OSTROUMOVA, I. N. 1957: Blood indexes and bloodcreating in the ontogenesis. Inf. VNIPRH, V.3, 43: 52-54

SERPUNIN, G. G. 1972: Characteristic of the bream Vislinsky lagoon blood. Graduated paper, Kaliningrad, 79 pp.

SERPUNIN, G. G. 1983: Haematological indexes of the carp in the intensive pond culture. Moscow, 23 p.

SERPUNIN, G. G. 1991: Using of the haematological analysis in the ichthyologic monitoring of the reservoirs. In: The second conference at fish industrial toxicology. Thesis, V.2: 169-170

SERPUNIN, G. G. 1998: Using of image analysis system „Videotest“ in ichthyohaematology. Proceedings of 4th Ichthyohaematological Conference. Hluboka n/Vlt.. Czech Republic, p. 23

SERPUNIN, G. G., AMINEVA, V. A. 1986: Method instructions to laboratory works at section „Physiology of the fish blood" to students of correspondence institutes at speciality 1013 ,Ichthyology and aquaculture“, Kaliningrad, $38 \mathrm{pp}$.

ZHITENEVA, L. D., POLTAVTSEVA, T. G., RUDNITSKAYA, O. A. 1989: Atlas of the normal and pathologic changed fish blood cells. Rostov-on-Don, $112 \mathrm{p}$. 